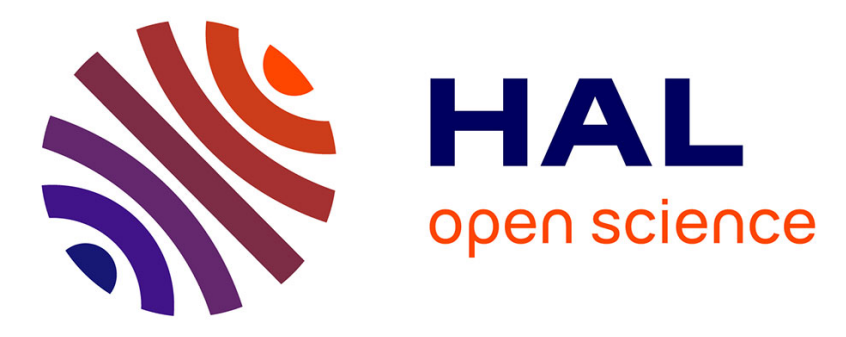

\title{
Improving estuarine net flux estimates for dissolved cadmium export at the annual timescale: Application to the Gironde Estuary
}

Aymeric Dabrin, Jörg Schäfer, Gérard Blanc, Emilie Strady, Matthieu

Masson, Cécile Bossy, Sabine Castelle, Naïg Girardot, Alexandra Coynel

\section{To cite this version:}

Aymeric Dabrin, Jörg Schäfer, Gérard Blanc, Emilie Strady, Matthieu Masson, et al.. Improving estuarine net flux estimates for dissolved cadmium export at the annual timescale: Application to the Gironde Estuary. Estuarine, Coastal and Shelf Science, 2009, 84 (4), pp.429-439. 10.1016/j.ecss.2009.07.006 . hal-02357371

\section{HAL Id: hal-02357371 \\ https://hal.science/hal-02357371}

Submitted on 14 Nov 2019

HAL is a multi-disciplinary open access archive for the deposit and dissemination of scientific research documents, whether they are published or not. The documents may come from teaching and research institutions in France or abroad, or from public or private research centers.
L'archive ouverte pluridisciplinaire HAL, est destinée au dépôt et à la diffusion de documents scientifiques de niveau recherche, publiés ou non, émanant des établissements d'enseignement et de recherche français ou étrangers, des laboratoires publics ou privés. 


\title{
Improving estuarine net flux estimates for dissolved cadmium export at the annual timescale: Application to the Gironde Estuary
}

\author{
Aymeric Dabrin, Jörg Scha" fer*, Ge'rard Blanc, Emilie Strady, Matthieu Masson, Ce'cile Bossy, \\ Sabine Castelle, Na"̈g Girardot, Alexandra Coynel
}

Universite' de Bordeaux, UMR 5805, EPOC, 33405 Talence, France

\section{a r t i c l e i n f o}

\section{Article history:}

Received 28 April 2009

Accepted 16 July 2009

Available online 23 July 2009

\section{Keywords:}

cadmium

Gironde Estuary

long term monitoring

annual dissolved net flux

\begin{abstract}
a b s t r a c t
Dissolved $C d\left(C_{D}\right)$ concentrations along the salinity gradient were measured in surface water of the Gironde Estuary during 15 cruises (2001-2007), covering a wide range of contrasting situations in terms of hydrology, turbidity and season. During all situations dissolved Cd concentrations displayed maximum values in the mid-salinity range, reflecting $\mathrm{Cd}$ addition by chloride-induced desorption and complexation. The daily net $\mathrm{Cd}_{\mathrm{D}}$ fluxes from the Gironde Estuary to the coastal ocean were estimated using Boyle's method. Extrapolating $\mathrm{Cd}_{\mathrm{D}}$ concentrations in the high salinity range to the freshwater end member using a theoretical dilution line produced 15 theoretical Cd concentrations $\left(\mathrm{Cd}^{0}{ }_{\mathrm{D}}\right)$, each representative of one distinct situation. The obtained Cd colpentrations were relatively similar (w201 T $28 \mathrm{ng} \mathrm{L}$ ) when freshwater discharge $Q$ was $>500 \mathrm{~m}^{3} \mathrm{~s}^{-1}\left(508 \leq Q \leq 2600 \mathrm{~m}^{3} \mathrm{~s}^{-1}\right)$, but were highly variable (340 T $\left.80 \mathrm{ng} \mathrm{L}^{-1} ; 247-490 \mathrm{ng} \mathrm{L}^{-1}\right)$ for low discharge situations $\left(169 \leq Q \leq 368 \mathrm{~m}^{3} \mathrm{~s}^{-1}\right)$. The respective daily $C d_{D}$ net fluxes were 5-39 $\mathrm{kg} \mathrm{day}^{-1}$, mainly depending on freshwater discharge. As this observation invalidates the existing method of estimating annual $C_{D}$ net fluxes, we proposed an empirical model, using representative $\mathrm{Cd}_{\mathrm{D}}^{0}$ values and daily freshwater discharges for the 2001-2007 period. Subsequent integration produced reliable $\mathrm{Cd}_{\mathrm{D}}$ net flux estimates for the Gironde Estuary at the annual timescale that ranged between 3.8-5.0 $\mathrm{t} \mathrm{a}^{-1}$ in 2005 and 6.0-7.2 $\mathrm{t} \mathrm{a}^{-1}$ in 2004, depending on freshwater discharge. Comparing $C_{D}$ net fluxes with the incoming $C_{D}$ fluxes suggested that the annual net $C d_{D}$ addition in the Gironde Estuary ranged from 3.5 to $6.7 \mathrm{t} \mathrm{a}^{-1}$, without any clear temporal trend during the past seven years. The annual CdD net fluxes did not show a clearly decreasing trend in spite of an overall decrease by a factor $w 6$ in Cd gross fluxes during the past decade. Furthermore, in six years out of seven (except 2003), the annual C d D net fluxes even exceeded river borne total (dissolved $p$ particulate) gross Cd fluxes into the estuary. These observations were attributed to progressive Cd desorption from both suspended particles and bottom sediment during various sedimentation-resuspension cycles induced by tidal currents and/or continuous dredging (navigation channel) and diverse intra-estuarine sources (wet deposition, urban sources, and agriculture). Provided that gross fluxes remain stable over time, dissolved Cd exportation from the Gironde Estuary to the coastal ocean may remain at the present level for the coming decade and the estuarine sedimentary $\mathrm{Cd}$ stock is forecast to decrease slowly.
\end{abstract}

\section{Introduction}

Hydrological, sedimentological and biogeochemical processes in estuarine systems strongly modify the quantity and the quality of river borne matter transported from the continent to the coastal ocean. Despite the need for reliable annual net flux data, estuarine net flux estimates are only available for the large minority of the global estuaries and cover very few, mostly dissolved, elements.

\footnotetext{
* Corresponding author.

E-mail address: j.schaefer@epoc.u-bordeaux1.fr (J.Scha" fer).
}

These estimates are usually valid for one particular day or distinct hydrological situation and, thus, extrapolation from the daily to the annual timescale suffers from many uncertainties due to hydrological variations and complex estuarine processes.

The Gironde Estuary (southwest France) is affected by historic metallic (e.g. Cd, Zn, Hg; Audry et al., 2004a; Scha" fer et al., 2006) contamination due to former $\mathrm{Zn}$ ore treatment in the industrial basin of Decazeville, that was stopped after a major pollution accident in 1986 (Jouanneau et al., 1999). Despite decreasing Cd inputs due to ongoing remediation efforts since the early 1990s, the Lot-Garonne River system still contributes up to $80 \%$ to the annual Cd gross fluxes into the Gironde Estuary (Scha“ fer et al., 2002b; Audry et al., 2004a). 
Moreover, important Cd stocks in the Lot River reservoir sediments (w2 00 t, Lapaquellerie et al.,1995) may be mobilized by flood events and/or dredging activities (e.g. Blanc et al., 1999; Audry et al., 2004b; Coynel et al., 2007). Numerous studies evidenced non-conservative behaviour of $\mathrm{Cd}$ along the salinity gradients in estuaries, bays or deltas (Boyle et al., 1982; Elbaz-Poulichet et al., 1987; Windom et al., 1988; Shiller and Boyle, 1991; Boutier et al., 1993; Chiffoleau et al., 1994; Wen et al., 1999; Tang et al., 2002). Typical profiles show a mid-salinity maximum in dissolved $C d\left(C d_{D}\right)$ reflecting the balance between chloride-induced desorption/complexation processes and dilution by seawater (e.g. Comans and van Dijk, 1988; ElbazPoulichet et al., 1996). Chloride induced-desorption is probably the major phenomenon that govern $\mathrm{Cd}$ behaviour in estuaries. However, several studies (e.g. Florence,1989; Baeyens et al.,1997; Waeles et al., 2005) have shown that organic ligands contribute also to keep Cd in solution in the high-salinity part of the estuaries. Dissolved $\mathrm{Cd}$ addition is particularly efficient in macrotidal estuaries due to relatively long particle residence times (Dyer, 1994). Several studies have reported $C d_{D}$ addition along the salinity gradient of the Gironde Estuary, suggesting that $\mathrm{w} 90 \%$ of the Cd gross fluxes are dissolved due to estuarine biogeochemical processes, thus increasing $\mathrm{Cd}$ availability to aquatic organisms (e.g. Jouanneau et al., 1990; Kraepiel et al., 1997; Boutier et al., 2000; Michel et al., 2000; Audry et al., 2007a,b; Lekhi et al., 2008). Although Cd concentrations in oysters from the Gironde Estuary have decreased from w1 $00 \mathrm{mg} \mathrm{g}^{-1}$ (dry weight) in the early 1980 s to $10-26 \mathrm{mgg}^{-1} \mathrm{~d}$.w. in 2006 (Claisse et al., 1992; RNO, French National Mussel Watch Program, 2006), they still are w25 times the average level measured along the entire French Atlantic and Mediterranean coasts (Boutier et al., 1989) and clearly exceed the current European consumption safety level for $\mathrm{Cd}$ in marine bivalves (5 $\mathrm{mg} \mathrm{g}^{-1}$, dry weight; CE No. 466/2001). As a consequence, oyster (bivalve) recovery and production are forbidden in the Gironde Estuary, i.e. this case of compromised/ affected ecosystem health goes along with social and economic effects. Furthermore, part of the water and particles exported from the Gironde Estuary to the coastal ocean reach the Marennes-Ole'ron Bay, i.e. one of Europe's most important oyster production zones, where Cd concentrations in oysters are clearly higher than in other bays along the French coast (Heral et al., 1982; Boutier et al., 2000; IFREMER, 2002). Therefore, precise estimates of annual dissolved Cd export from the Gironde Estuary to the coastal zone are essential to assess $\mathrm{Cd}$ sources and inputs into the Marennes-Ole' ron Bay. Reliable $\mathrm{Cd}_{\mathrm{D}}$ net flux estimates need concentration data in the estuarine high-salinity range, where $\mathrm{Cd}_{\mathrm{D}}$ values follow a theoretical mixing line. Extrapolation of this dilution line to $S 1 / 40$, produces a theoretical freshwater $\mathrm{Cd}_{\mathrm{D}}$ concentration $\left(\mathrm{Cd}_{\mathrm{D}}^{\mathrm{D}}\right)$, that may be multiplied by the daily freshwater discharge $\left(Q_{i}\right)$ to estimate daily $C d_{D}$ net flux (Boyle et al., 1974). Integration of 365 discrete daily $C_{D}$ net fluxes would then provide precise annual flux estimates, but this "ideal" strategy also would be far too expensive and time-consuming. Accordingly, the existing estimates of $\mathrm{Cd}_{\mathrm{D}}$ net fluxes in the Gironde Estuary and other estuaries are based on few measurement campaigns, each providing one daily ("snapshot") dataset, i.e. one $\mathrm{Cd}_{\mathrm{D}}^{0}$ value. Therefore, extrapolation of these daily $\mathrm{Cd}$ net fux estimates to the annual timescale may imply important uncertainty. Elbaz-Poulichet et al. (1987) estimated an annual net $\mathrm{Cd}_{\mathrm{D}}$ flux of 14 $\mathrm{t} \mathrm{a}^{-1}\left(37 \mathrm{~kg}\right.$ day $\left.{ }^{-1}\right)$ based on one measurement campaign in October 1982. Boutier et al. (2000) estimated annual $\mathrm{Cd}_{\mathrm{D}}$ net fluxes in 1991 to $11 \mathrm{t} \mathrm{a}^{-1}$ (44 $\mathrm{kg}$ day ${ }^{-1}$ ), based on one $\mathrm{Cd}^{0}$ value, i.e. one measurement campaign. During five sampling campaigns in the hydrological year 1997-1998, Michel et al. (2000) obtained similar daily $\mathrm{Cd}_{\mathrm{D}}$ net fluxes for contrasting seasons/discharges and concluded that daily $\mathrm{Cd}_{\mathrm{D}}$ net fluxes (w17 $\mathrm{kg}$ day ${ }^{-1}$ ) out of the Gironde Estuary would be constant throughout the year. Since the early nineties, Cd gross fluxes into the Gironde estuary have decreased probably due to ongoing remediation in the watershed and apparently changing hydrological conditions (Scha" fer et al., 2002a,b; Masson et al., 2006) suggesting profound changes in the Cd budget of the Gironde Estuary. There is, however, at present no estimate of recent annual $\mathrm{Cd}_{\mathrm{D}}$ net fluxes in the Gironde Estuary taking into account potential interannual and seasonal variations.

This work is based on a unique data set of dissolved Cd distributions along the Gironde Estuary salinity gradient, obtained from 15 measurement campaigns over 7 years (2001-2007) covering contrasting hydrological situations (e.g. freshwater discharges, tidal coefficients) and seasons. The aim of this study is to provide recent data on $\mathrm{Cd}_{\mathrm{D}}$ net fluxes and to evaluate the variability and long-term evolution of $C_{D}$ export from the Gironde Estuary to the coastal ocean. Based on the relationship between $\mathrm{Cd}_{\mathrm{D}}$ distribution along the salinity gradient and freshwater discharge we propose an improved method of extrapolating daily $\mathrm{Cd}_{\mathrm{D}}$ net fluxes to the annual timescale. Additionally, we compare recent $\mathrm{Cd}_{\mathrm{D}}$ addition and net fluxes to historic data to assess the response of the estuarine Cd budget to generally decreasing gross inputs.

\section{Study area}

The physical, geochemical and hydrological characteristics of the Gironde Estuary (w170 km length, w $80000 \mathrm{~km}^{2}$ watershed surface area; Fig. 1) have been well defined in several studies (Elbaz-Poulichet et al., 1984; Li et al., 1994; Sottolichio and Castaing, 1999; Scha" fer et al., 2002b). The Gironde Estuary has a mean annual freshwater discharge of $\mathrm{w} 1000 \mathrm{~m}^{3} \mathrm{~s}^{-1}$ with typical water and particle residence times of w20-90 days and w1-2 years, respectively (Jouanneau and Latouche, 1981). During the tidal cycle, ocean water fluxes at the estuary mouth are 30-40 times higher than fluvial inputs (Allen et al., 1977). Asymmetrical progression of the tidal wave toward the upstream estuary induces a pronounced maximum turbidity zone (MTZ), where concentrations of suspended particulate matter (SPM) exceed $1 \mathrm{~g} \mathrm{~L}^{-1}$ in surface water and several hundreds of $\mathrm{g} \mathrm{L}^{-1}$ in bottom water. This MTZ is typically located in the low salinity region and migrates up and down estuary with seasonal river flow variations (Sottolichio and Castaing, 1999). Sediment resuspension generally occurs during erosion periods at mid-ebb and mid-flood while tidal slacks are sedimentation periods. As a consequence of sedimentation, the navigation channel (w18 $\mathrm{km}^{2}$ ) of the estuary is continuously dredged by the Bordeaux Autonomous Harbour (P.A.B.). The dredged sediments are either dispersed in the water column on-site or transported downstream within the estuary and deposited in distinct zones, where they are dispersed and/or resuspended by tidal currents (Audry et al., 2007a,b).

\section{Material and methods}

\subsection{Sampling}

Samples were collected during 15 cruises within the Gironde Estuary between March 2001 and November 2007 along the salinity gradient onboard the RV "Co^tes de la Manche" (INSU). These sampling campaigns cover a wide range of freshwater discharges (Table 1), which were calculated as the sum of the daily flows of the Garonne and Dordogne Rivers (Fig. 2). Sampling of surface and bottom water in the estuarine salinity gradient was performed with acid-cleaned Niskin Bottles, thoroughly rinsed with estuarine water from the site. The samples were immediately filtered through cellulose acetate syringe filters (Sartorius ${ }^{\circledR}, 0.2 \mathrm{~mm}$ porosity). Aliquots for trace metals measurements were transferred into $125 \mathrm{~mL}$ acid-cleaned polypropylene bottles, acidified $(\mathrm{pH} 1$; $\mathrm{HNO}_{3}$ Baker ultrapure) and stored in the dark at $4{ }^{\circ} \mathrm{C}$. 


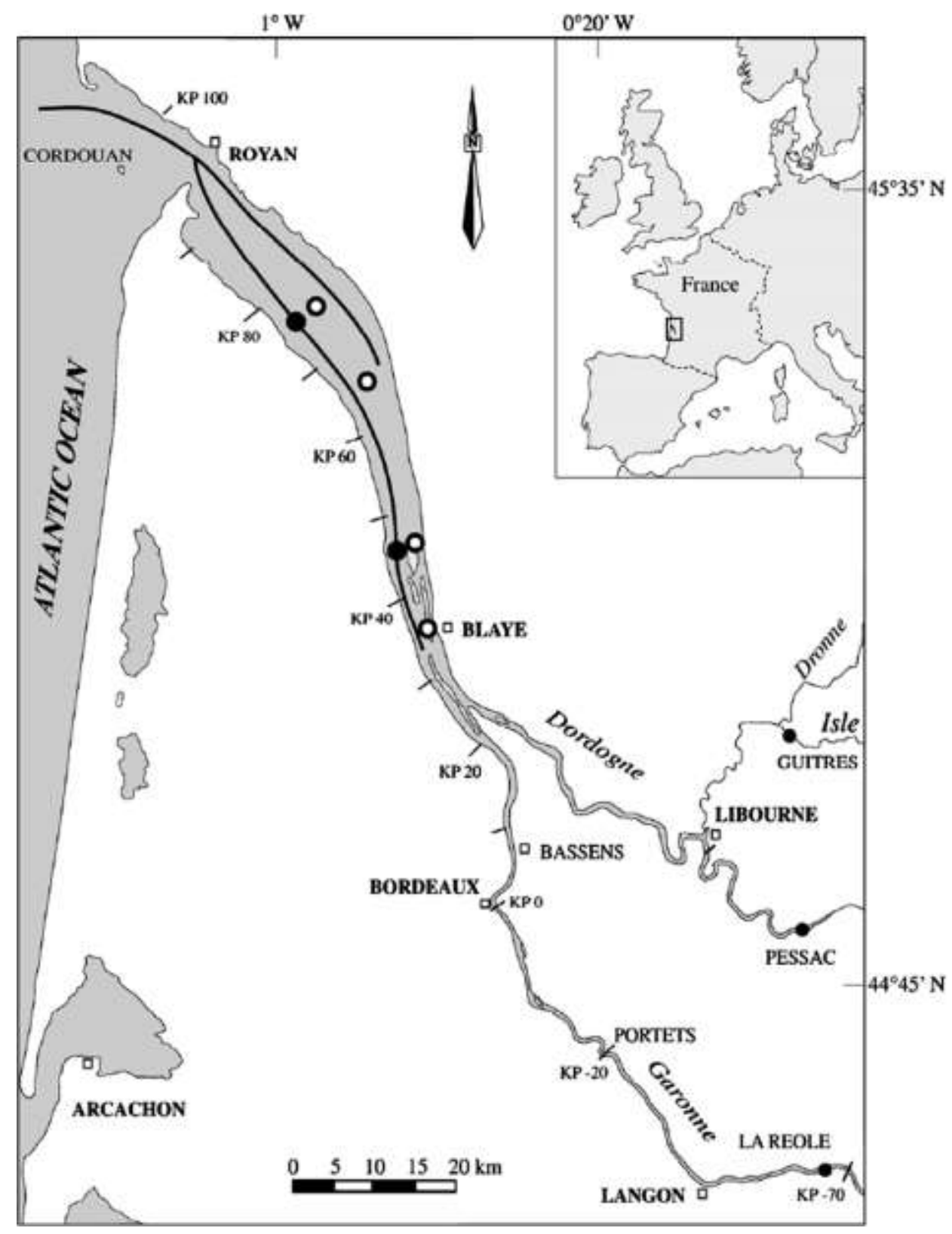

Fig. 1. Map of the Gironde Estuary. Kilometric Points (KP) $1 / 4$ distance $(\mathrm{km})$ from the city of Bordeaux.

\subsection{Sample analyses}

Determination of SPM concentrations was performed by filtration using dry pre-weighed filters (Durieux glass-fibre, $0.7 \mathrm{~mm}$ porosity) as described elsewhere (e.g. Audry et al., 2004a; Masson et al., 2006). The filters were dried to constant weight $\left(50^{\circ} \mathrm{C}\right)$ and reweighed. Analyses of dissolved metals were performed after matrix separation and preconcentration by liquid-solid extraction, to avoid interferences induced by major cations during instrumental analysis. In this work, we used commercially available cartridges (DigiSEP Blue ${ }^{\circledR}$; SCP Science) with amino-diacetate as the functional group that has strong affinities to several divalent transition metal cations (e.g. $\mathrm{Cd}, \mathrm{Cu}, \mathrm{Co}$, etc.). The samples $(50 \mathrm{~mL})$ with $\mathrm{pH}$ adjusted to $5.3 \mathrm{~T} 0.1$ were passed (flowrate $2 \mathrm{~mL} \mathrm{~min}^{-1}$ ) through the acidcleaned and conditioned column $(0.1 \mathrm{M}$ ammonium acetate buffer; $\mathrm{pH}$ 5.3). Then the cartridges were rinsed with $5 \mathrm{~mL}$ of buffer solution and trace metals were eluted with nitric acid (2 M, SCP-Science plasmapurePlus). Dissolved Cd concentrations were measured using
ICP-MS (X7, Thermo) with external calibration. Column blanks were performed by passing $50 \mathrm{~mL}$ Milli-Q water under identical conditions, parallel to the samples and certified reference materials. Methodological blanks obtained for $\mathrm{Cd}$ were generally lower than $2 \mathrm{ng} \mathrm{L}^{-1}$ and were systematically subtracted from results obtained for the other samples. Detection limit (3.3 times the standard deviation of blank values; $n 1 / 456$ ) was $6 \mathrm{ng} \mathrm{L}^{-1}$. Reproducibility and accuracy of the method were assessed by analyzing certified refer-

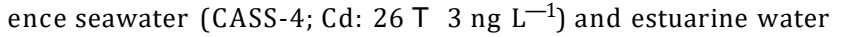
(SLEW-3; Cd: $48 \mathrm{~T}_{4} \mathrm{ng} \mathrm{L}^{-1}$ ). For both reference materials, reproducibility was generally better than $3 \%($ rsd; $n 1 / 425)$ and accuracy was respectively $99 \%$ and $98 \%$ of the certified values.

\section{3. $C d^{0}{ }^{0}$ determination}

The commonly applied method for estimating dissolved metal net fluxes (Boyle et al., 1974) is based on the dissolved element distribution in the high salinity zone. According to Boyle et al. 
each regression, equations of the dilution lines, and the resulting theoretical $\mathrm{Cd}_{\mathrm{D}}^{0}$ concentrations ( $\mathrm{ng} \mathrm{L}^{-1}$, bold numbers) at $S^{1 / 4} 0$ and daily Cd net flux estimates ( $\mathrm{kg}$ day- $\mathrm{Y}$. All the relationships are statistically significant at the $95 \%$ confidence level.

\begin{tabular}{|c|c|c|c|c|c|c|c|c|}
\hline Cruise & & $\begin{array}{l}\text { Discharge } \\
\left(\mathrm{m}^{3} \mathrm{~s}^{-1}\right)\end{array}$ & $\mathrm{PK}$ range & Salinity range & Linear regression & $n$ & $R^{2}$ & $\begin{array}{l}\text { Daily flux } \\
\text { (kg day }^{-1} \text { ) }\end{array}$ \\
\hline \multicolumn{9}{|l|}{ Flood events } \\
\hline Gimet 2 & March 2001 & 2040 & $0-100$ & $15-29$ & {$[\mathrm{Cd}]{ }^{1 / 4}-6.4(\mathrm{~T} 3.4)[S]$ p $222(\mathrm{~T} 79)$} & 8 & 0.79 & 39 ( ( 1 14) \\
\hline Gimercad 3 & March 2007 & 2600 & $0-85$ & $12-26$ & {$[\mathrm{Cd}] 1 / 4-3.8(\mathrm{~T} 2.9)[\mathrm{S}]$ b $160(\mathrm{~T} 56)$} & 4 & 0.77 & $36(\mathrm{~T} 13)$ \\
\hline \multicolumn{9}{|c|}{ Intermediate freshwater discharge } \\
\hline Gimet 3 & June 2001 & 546 & $0-100$ & $17-32$ & {$[\mathrm{Cd}] 1 / 4-6.4(\mathrm{~T} 2.7)[\mathrm{S}]$ p $230(\mathrm{~T} 65)$} & 6 & 0.92 & $11(\mathrm{~T} 3.1)$ \\
\hline Girox 1 & February 2002 & 508 & $0-100$ & $18-32$ & {$[\mathrm{Cd}] 1 / 4-4.5(\mathrm{~T} 0.7)[\mathrm{S}]$ b 176 (T19) } & 9 & 0.97 & $8(\mathrm{~T} 0.8)$ \\
\hline Reagir 3 & May 2005 & 687 & $0-100$ & $15-30$ & {$[\mathrm{Cd}] 1 / 4-5.7(\mathrm{~T} 0.5)[\mathrm{S}]$ p $219(\mathrm{~T} 11)$} & 6 & 0.99 & $13(\mathrm{~T} 0.7)$ \\
\hline Gimercad 1 & May 2006 & 705 & $0-100$ & $19-30$ & $[\mathrm{Cd}]]^{1 / 4}-5.0(\mathrm{~T} 1.4)[\mathrm{S}]$ p $202(\mathrm{~T} 37)$ & 6 & 0.96 & $12(\mathrm{~T} 2.3)$ \\
\hline \multicolumn{9}{|c|}{ Low freshwater discharge } \\
\hline Girox 2 & September 2002 & 368 & $0-100$ & $23-31$ & $[\mathrm{Cd}]]^{1 / 4}-4.8(\mathrm{~T} 1.1)[S]$ p 247 (T31) & 7 & 0.96 & $8(\mathrm{~T} 1.0)$ \\
\hline Girox 4 & September 2003 & 207 & $0-100$ & $27-33$ & {$[\mathrm{Cd}] 1 / 4-13.0(\mathrm{~T} 1.2)[S]$ p $490(\mathrm{~T} 38)$} & 6 & 0.99 & $9(\mathrm{~T} 0.7)$ \\
\hline Reagir 1 & July 2004 & 310 & $0-100$ & $20-34$ & [Cd] 1/4 -7.6(T1.6)[S] p $296(\mathrm{~T} 44)$ & 9 & 0.96 & $8(T 1.2)$ \\
\hline Reagir 2 & October 2004 & 304 & $0-100$ & $21-31$ & {$[\mathrm{Cd}] 1 / 4-8.5(\mathrm{~T} 3.2)[S]$ p $324(\mathrm{~T} 88)$} & 6 & 0.93 & $9(\mathrm{~T} 2.3)$ \\
\hline Metogir 1 & July 2005 & 304 & $0-100$ & $25-34$ & $[\mathrm{Cd}]]^{1 / 4}-10.2(\mathrm{~T} 1.5)[\mathrm{S}]$ b $367(\mathrm{~T} 46)$ & 7 & 0.99 & $10(\mathrm{~T} 1.2)$ \\
\hline Reagir 4 & November 2005 & 319 & $0-90$ & $17-31$ & {$[\mathrm{Cd}]^{1 / 4}-6.3(\mathrm{~T} 5.3)[S]$ p $264(\mathrm{~T} 120)$} & 6 & 0.93 & $7(T 3.3)$ \\
\hline Gimercad 2 & September 2006 & 169 & $0-100$ & $23-33$ & {$[\mathrm{Cd}]$ 1/4-10.4 (T1.8)[S] p $399(\mathrm{~T} 53)$} & 10 & 0.95 & $6(\mathrm{~T} 0.8)$ \\
\hline Gimercad 4 & October 2007 & 305 & $0-100$ & $24-34$ & {$[\mathrm{Cd}] 1 / 4-10.4(\mathrm{~T} 2.3)[S]$ p $400(\mathrm{~T} 69)$} & 6 & 0.98 & $11(\mathrm{~T} 1.8)$ \\
\hline Gimercad 5 & November 2007 & 209 & $0-100$ & $23-30$ & {$[\mathrm{Cd}]^{1 / 4}-7.2(\mathrm{~T} 3.4)[S]$ p $273(\mathrm{~T} 105)$} & 4 & 0.98 & $5(\mathrm{~T} 1.9)$ \\
\hline
\end{tabular}

$(1974,1982)$, the instant net flux $\left(F_{t}\right)$ of a dissolved element $X$ across an isohaline $S$ at a time $t$ is:

$F_{t}^{1 / 4} Q_{1 / 4 X]-1 / \delta} \quad \frac{\left.d^{1} / 2\right]^{2}}{\left.d^{1} / 2 S\right]}$

where $[S]$ is salinity, $[X]$ the concentration of the element of interest, and $Q_{t}$ the freshwater discharge at time $t$. If the relation between the dissolved element concentration and the salinity is linear (conservative behaviour), $\mathrm{d}[X] / \mathrm{d}[S]$ is constant and equal to the slope of the segment representing this relation in the concentration-salinity diagram. In this case, for any salinity [S] belonging to the linearity range, $[X]_{S}-[S]^{*}\left(\mathrm{~d}[X]_{S} / \mathrm{d}[S]\right)$ is constant and equal to the intercept $[X]_{0}$ of the straight line extrapolated from this segment, and the net instant flux of the element through any isohaline in the linearity range is:

\section{$F_{t} 1 / 4 Q_{t} 1 / 2 X_{0}$}

As perfect linearity is rarely observed in any salinity range, a linear regression technique is applied to obtain the most probable intercept, which is then used to estimate the net instant flux of any dissolved element. The salinity range used for this calculation should be representative of the geographic zone selected and should include the isohaline through which the flux estimation is to be made. The salinity range was determined in order to maximize the correlation coefficient. Daily net flux $\left(F_{\mathrm{NET}}\right)$ can be estimated as:

$\left.F_{\mathrm{NET}}{ }^{1 / 4} Q_{f w}{ }^{1 / 2 X}\right]_{0}$

where $Q_{f w}$ is the daily river discharge.

\section{Results}

\subsection{Hydrologic conditions}

The fifteen cruises are representative of a 7-years period covering contrasting hydrologic conditions and different seasons (Fig. 2, Table 1). Except for 2003, two campaigns per year were performed. Freshwater discharges during the different sampling cruises ranged from $169 \mathrm{~m}^{3} \mathrm{~s}^{-1}$ (September 2006) to $2600 \mathrm{~m}^{3} \mathrm{~s}^{-1}$ (March 2007).

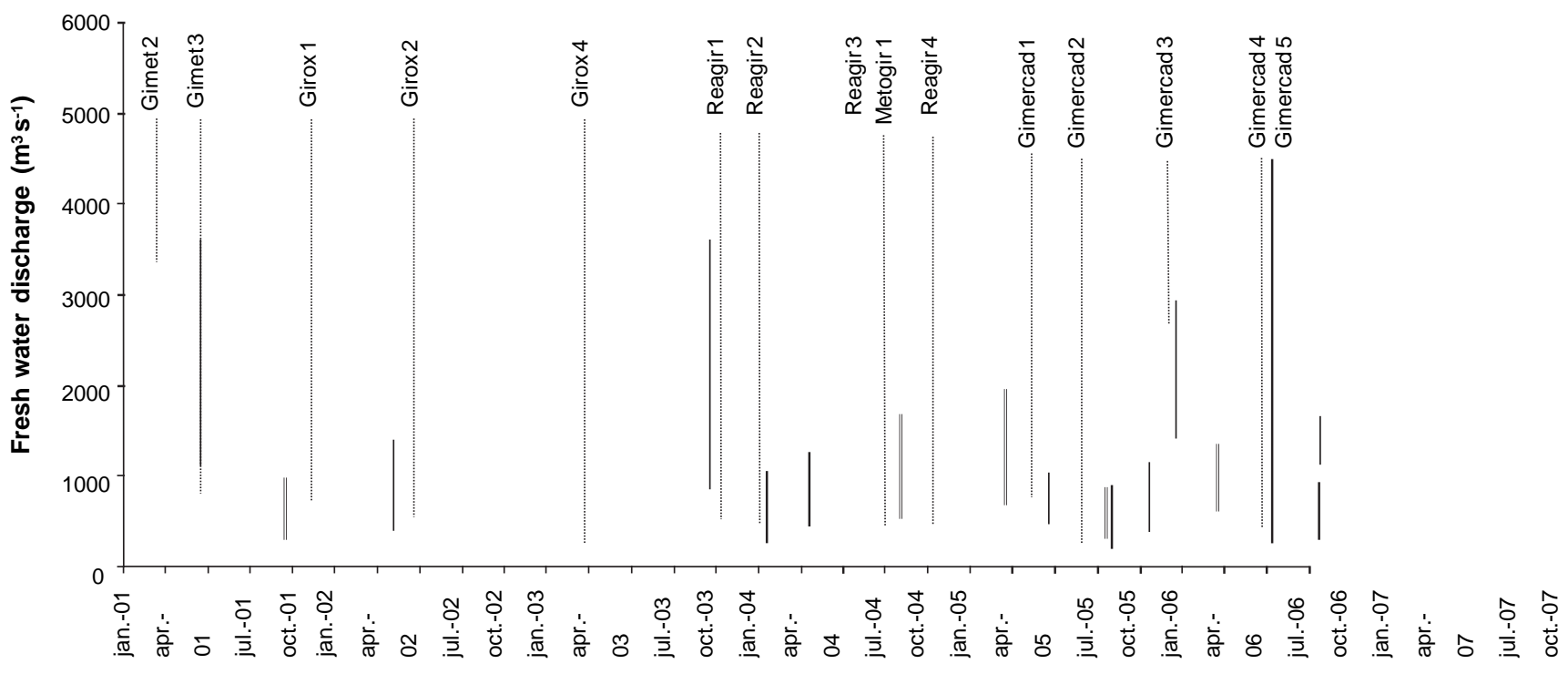

Fig. 2. Freshwater discharges of the Gironde Estuary during the 2001-2007 period. 
Based on freshwater discharge data, the studied hydrological situations may be classified as follows: (a) low freshwater discharge during summer and autumn $\left(<500 \mathrm{~m}^{3} \mathrm{~s}^{-1}\right.$; September 2002, September 2003, July 2004, October 2004, July 2005, November 2005, October 2007 and November 2007), (b) intermediate discharge during the winter/spring period (500-700 $\mathrm{m}^{3} \mathrm{~s}^{-1}$; June 2001, February 2002, May 2005 and June 2006) and (c) the flood events ( $>2000 \mathrm{~m}^{3} \mathrm{~s}^{-1}$; March 2001, March 2007). Although the sampled periods cover a very wide range of discharge situations in the Gironde Estuary, the discharge range from 750 to $2000 \mathrm{~m}^{3} \mathrm{~s}^{-1}$ has not been sampled. During the 2001-2007 period, hydrological situations with freshwater discharges comprised between 750 and $2000 \mathrm{~m}^{3} \mathrm{~s}^{-1}$ only occurred during $\mathrm{w} 25 \%$ of the time. Accordingly, the sampled periods represent hydrological situations covering w75\% of the time during 2001-2007.

\subsection{Dissolved $\mathrm{Cd}$ distribution along the salinity gradient}

The $C_{D}$ concentrations of the first 2 cruises (Gimet 2, Gimet 3 ) have already been presented in an earlier study with a different focus (Audry et al., 2007a,b) and are presented here together with original data obtained during 13 additional cruises to increase the representativity of the present work. Dissolved $C d\left(C_{D}\right)$ concentrations in surface waters along the salinity gradient displayed a similar distribution during all 15 cruises (Fig. 3). In the freshwater reaches, $C d_{D}$ concentrations were generally close to $20 \mathrm{ng} \mathrm{L}^{-1}$ (Fig. 3; Audry et al., 2007a,b). In the low-salinity range $(S<15)$, dissolved $\mathrm{Cd}$ concentrations increased with salinity reaching maximum values of $98 \mathrm{ng} \mathrm{L}^{-1}$ (November 2007) to $166 \mathrm{ng} \mathrm{L}^{-1}$ (September 2003) in the mid-salinity range ( $S$ w 15-20). In contrast, in the high-salinity range $(S>20), C_{D}$ behaved conservatively, i.e. showed a linear decrease with salinity (Fig. 3). The dissolved $\mathrm{Cd}$ concentrations obtained for bottom water profiles fit with the concentrations in surface waters, except during the flood event (March 2007) when bottom water concentrations were higher and more variable.

\section{Discussion}

\subsection{Cadmium chlorocomplexation and variations of the maximum $C d_{D}$ values}

The $\mathrm{Cd}_{\mathrm{D}}$ concentrations observed for the 15 profiles (8- $166 \mathrm{ng}$ $\mathrm{L}^{-1}$; Fig. 3) were in the same range as those measured during the previous decade (Kraepiel et al.,1997; Boutier et al., 2000; Michel et al., 2000). The maximum values were higher than those reported for heavily industrialised/urbanised estuaries, such as the Seine (Chiffoleau et al., 1999), the Loire (Waeles et al., 2004) and the Scheldt Estuaries (Zwolsman et al., 1997), but they were clearly lower than those of in the Rio Tinto, which is severely impacted by acid-mine drainage (Braungardt et al., 2003) or in the Mersey Estuary, which drains a heavily populated and highly industrialised area (Martino et al., 2002).

The observed dissolved Cd distributions of all the campaigns showed typical non-conservative behaviour of $\mathrm{Cd}$ as observed in other macrotidal estuaries, e.g. the Tay (Owens and Balls, 1997), the Charente (Boutier et al., 2000), the Loire (Boutier et al., 1993; Waeles et al., 2004), the Scheldt (Zwolsman et al., 1997) and the Seine Estuaries (Chiffoleau et al., 1994, 1999). The commonly observed dissolved $\mathrm{Cd}$ addition in the low salinity range $(S<15)$ has been attributed to chloride-induced desorption of particlebound $\mathrm{Cd}$ and formation of stable dissolved chlorocomplexes (e.g. Elbaz-Poulichet et al., 1987; Comans and van Dijk, 1988; Turner et al., 1993; Turner, 1996). The apparently conservative behaviour in the mid- to high-salinity range (wlinear decrease in $\mathrm{Cd}_{\mathrm{D}}$ concentrations with increasing salinity) may be attributed to dilution of mid-salinity high $\mathrm{Cd}_{\mathrm{D}}$ waters by oceanic, low $\mathrm{Cd}_{\mathrm{D}}$ water. This, in turn, suggests that the suspended particles in the high salinity range are depleted in easily desorbable $\mathrm{Cd}$.

Like the low- to intermediate discharge situations, both flood situations (March 2001 and March 2007) showed a clear increase in the low-salinity range, but the mid-salinity maximum was much less defined, i.e. the data were more scattered than during low discharge situations (Fig. 3). This may suggest that floods modify the typical $\mathrm{Cd}_{\mathrm{D}}$ distribution along the salinity gradient, eventually due to (a) local resuspension of bottom sediment (Sottolichio and Castaing, 1999) enriched in dissolved and particulate Cd (Audry et al., 2006) and/or (b) very short water residence times (w2 0 days, Jouanneau and Latouche, 1981) with incomplete mixing of "fresh" Cd-rich and "old" Cd-depleted particles. In fact, fluvial inputs of dissolved and particulate $\mathrm{Cd}$ by the Garonne, Dordogne and Isle Rivers are at maximum during floods (Scha" fer et al., 2002b; Masson et al., 2006). The particle fluxes from the watershed to the estuary during major flood events (e.g. w0.8-1 Mt in 6 days in February 2003; Coynel et al., 2007) may be equivalent to $20-25 \%$ of the particle mass in the MTZ (4-5 Mt; Jouanneau et al., 1990). This may modify the composition of the estuarine particle pool, especially for reactive carrier phases and associated elements that undergo profound changes in the estuarine geochemical gradients, inducing local heterogeneities in particle composition and reactivity. This hypothesis may be supported by the similarity between $\mathrm{Cd}_{\mathrm{D}}$ concentrations in surface and bottom water profiles during low-and intermediate discharge (Fig. 3), suggesting that the water column was well-mixed under these hydrologic conditions. In contrast, during the floods, clear $\mathrm{Cd}_{\mathrm{D}}$ concentration differences between surface and bottom water were observed and attributed to (a) the impact of sediment remobilisation including porewater release into the water column and/or (b) incomplete mixing and variable residence times of different water masses and particles.

Although freshwater discharges during the different cruises varied by a factor 16 , maximum $\mathrm{Cd}_{\mathrm{D}}$ concentrations in the midsalinity range of each profile showed only little variability, ranging from $98 \mathrm{ng} \mathrm{L}^{-1}$ to $166 \mathrm{ng} \mathrm{L}^{-1}$ (Fig. 3). Interestingly, there was no systematic difference in the maximum $\mathrm{Cd}_{\mathrm{D}}$ for the different types of hydrological situations. This observation is not what would have been expected, presuming dilution of dissolved Cd in the estuary by freshwater inputs during floods. In fact, one would have expected maximum $\mathrm{Cd}_{\mathrm{D}}$ mid-salinity levels during low water discharge, when long residence times of water (up to 3 months), and particles ( $>2$ years) should account for most efficient $\mathrm{Cd}$ desorption (Jouanneau and Latouche, 1981). Furthermore, neither the position nor the SPM concentration level in the MTZ seem to control maximum $\mathrm{Cd}_{\mathrm{D}}$ concentrations in the Gironde Estuary (Fig. 3).

\subsection{Temporal variations in the theoretic $C d_{D}$ concentrations at zero salinity}

The theoretic $\mathrm{Cd}_{\mathrm{D}}$ concentrations at zero salinity $\left(\mathrm{Cd}_{\mathrm{D}}^{0}\right)$ obtained from applying Boyle's method to the different longitudinal profiles are reported in Table 1. During the flood events, $\mathrm{Cd}_{\mathrm{D}}^{0}$ concentrations were $222 \mathrm{ng} \mathrm{L}^{-1}$ in March $2001\left(2040 \mathrm{~m}^{3} \mathrm{~s}^{-1}\right)$ and $160 \mathrm{ng} \mathrm{L}^{-1}$ in March $2007\left(2600 \mathrm{~m}^{3} \mathrm{~s}^{-1}\right)$. This is in good agreement with $\mathrm{Cd}^{0}$ D (206 $\mathrm{n} \mathrm{L} \mathrm{L}^{-1}$ ) obtained from previously reported data on dissolved $\mathrm{Cd}$ concentrations in the Gironde Estuary during a comparable hydrologic situation in $1994\left(Q^{1 / 4} 2100 \mathrm{~m}^{3} \mathrm{~s}^{-1}\right.$; Kraepiel et al., 1997). For intermediate freshwater discharge conditions (2001-2007

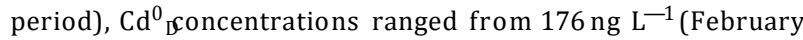
2002; $Q^{1 / 4} 508 \mathrm{~m}^{3} \mathrm{~s}^{-1}$ ) to $230 \mathrm{ng} \mathrm{L}^{-1}$ (June 2001; $Q^{1 / 4} 546 \mathrm{~m}^{3} \mathrm{~s}^{-1}$ ), i.e. were rather similar to those observed during floods. 

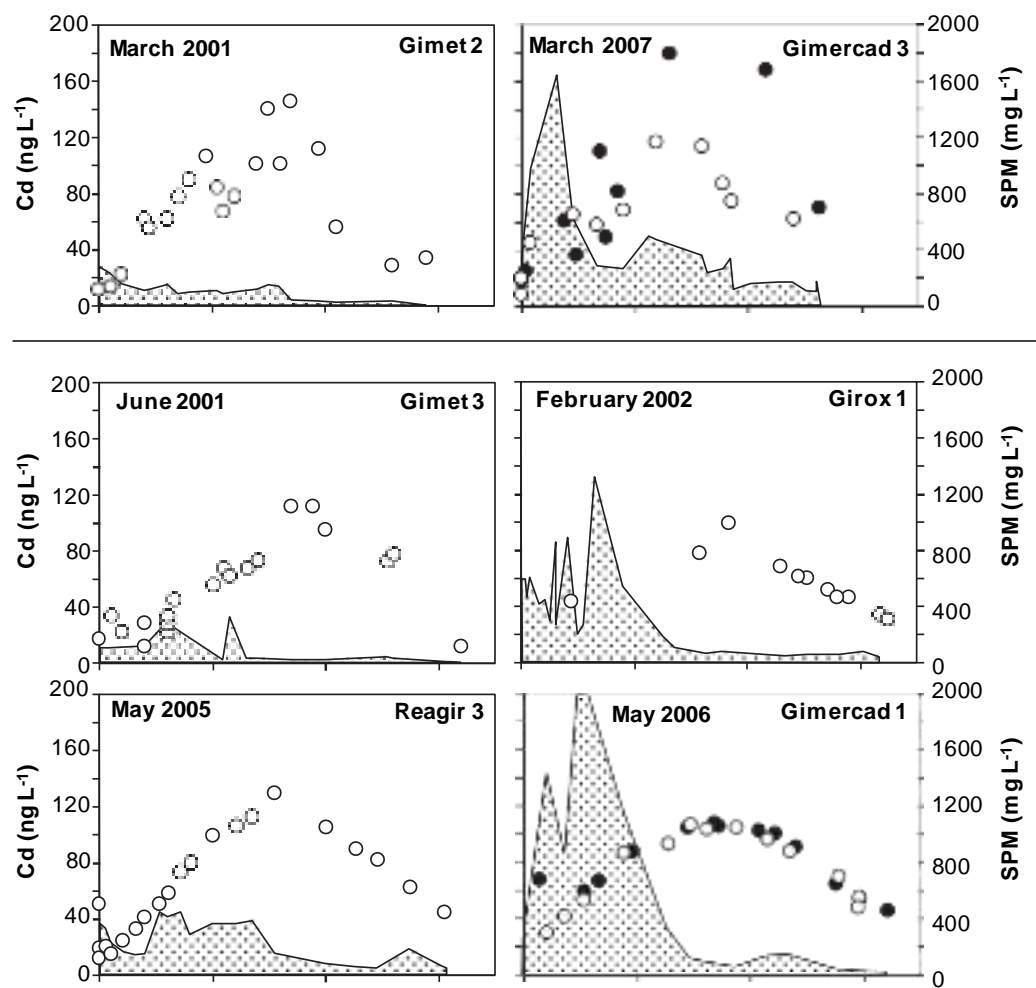

b
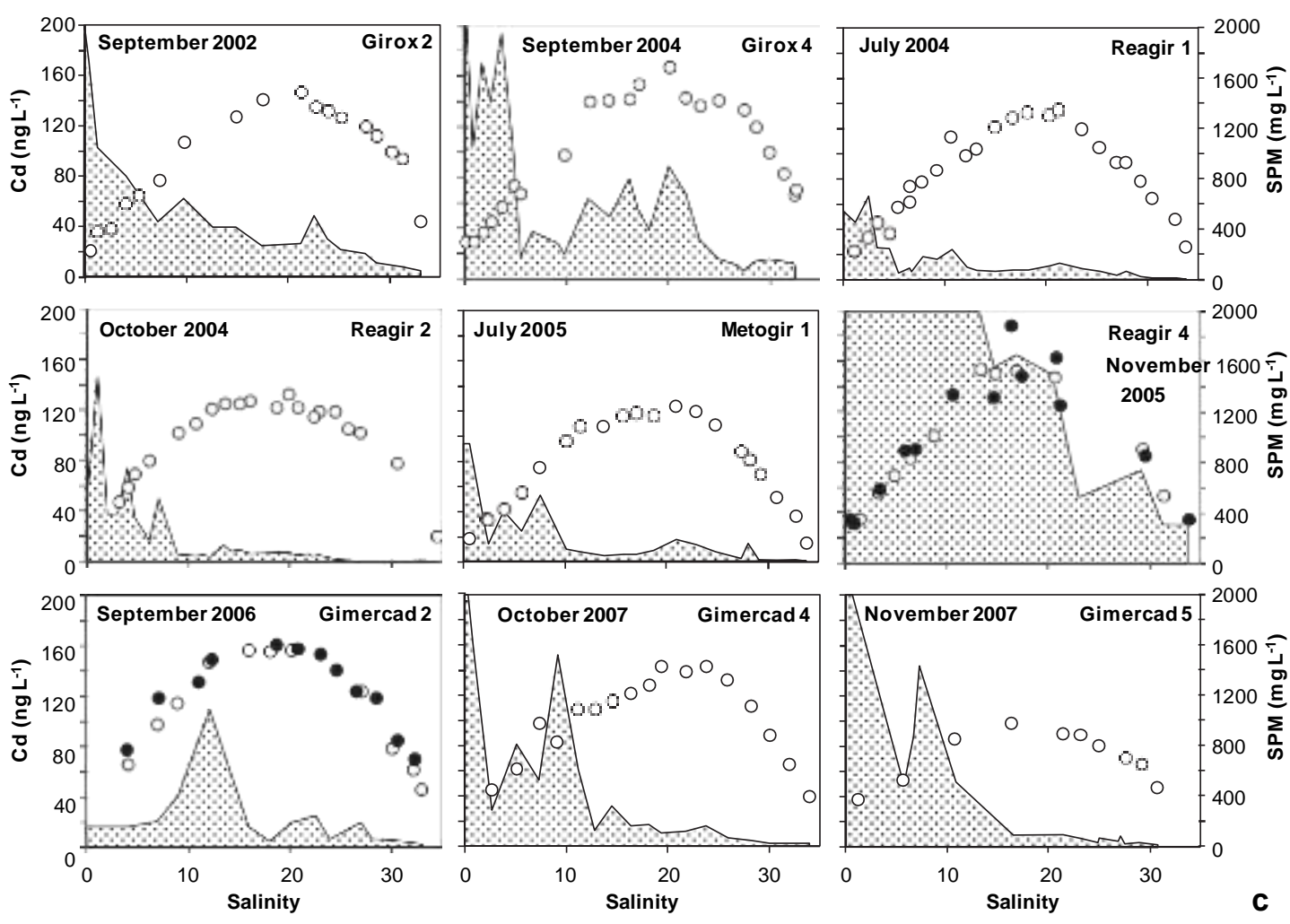

Fig. 3. Distribution of dissolved Cd and suspended particulate matter along the salinity gradient for (a) flood events, (b) intermediate discharge and (c) low discharge. Dotted areas represent surface water SPM concentrations, open circles represent $C_{D}$ concentrations in surface water and full circles represent $C d_{D}$ in bottom water. Note that the $C_{D}$ values for the Gimet 2 and 3 cruises (March and June 2001) are from Audry et al. (2007a).

In contrast, clearly higher $\mathrm{Cd}_{\mathrm{D}}^{0}$ values may be deduced from older data measured during intermediate freshwater discharge in 1984

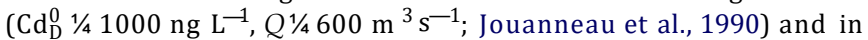

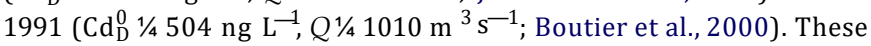

results are consistent with strongly reduced emissions after the stop of the ore treatment activity (1987) and gradually decreasing particulate Cd concentrations of SPM in the fluvial-estuarine system, which is further supported by sedimentary records in Lot River 
reservoir lakes (e.g. Audry et al., 2004b) and in the flood-tidal dock at Bordeaux (Grousset et al., 1999).

During low freshwater discharge $\left(Q<500 \mathrm{~m}^{3} \mathrm{~s}^{-1}\right), \mathrm{Cd}^{0}$ concentrations varied by a factor 2 and ranged from $247 \mathrm{ng} \mathrm{L}^{-1}$ (September 2002; $Q^{1 / 4} 368 \mathrm{~m}^{3} \mathrm{~s}^{-1}$ ) to $490 \mathrm{ng} \mathrm{L}^{-1}$ (September 2003;

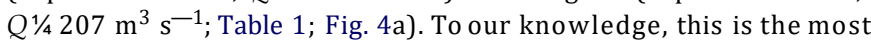
complete ( 9 campaigns) data set on $\mathrm{Cd}^{0}{ }_{\mathrm{D}}$ values covering most low freshwater discharge situations in the same estuary during consecutive years (2002-2007). This dataset is the first to show the great variability of the $\mathrm{Cd}^{0}$ goncentration during low freshwater discharge $\left(Q<500 \mathrm{~m}^{3} \mathrm{~s}^{-1}\right.$; Fig. 4a). The observed variations probably reflect the balance of desorption efficiency, residence time of water and particles in the estuary and mixing of fresh- and seawater. Such non-steady state conditions may eventually result from several factors. First, variations in the input of freshwater particles (rich in desorbable $\mathrm{Cd}$ ) or urban particles from Bordeaux may enhance addition, especially during low discharge, when particle residence time in the estuary is long (Sottolichio and Castaing, 1999). Second, variable $C d_{D}$ release may be due to sediment and/or fluid mud resuspension by tidal currents and/or dredging (Robert et al., 2004; Audry et al., 2007a,b). Third, $\mathrm{O}_{2}$-depletion in the bottom of the water column during low freshwater discharge (Abril et al., 1999) could eventually induce removal processes, e.g. by sulphide precipitation, as reported for the Scheldt Estuary (Zwolsman et al., 1997) temporarily and locally limiting Cd addition. However, the well-mixed Gironde Estuary generally displays relatively high oxygen concentrations in most of the water column
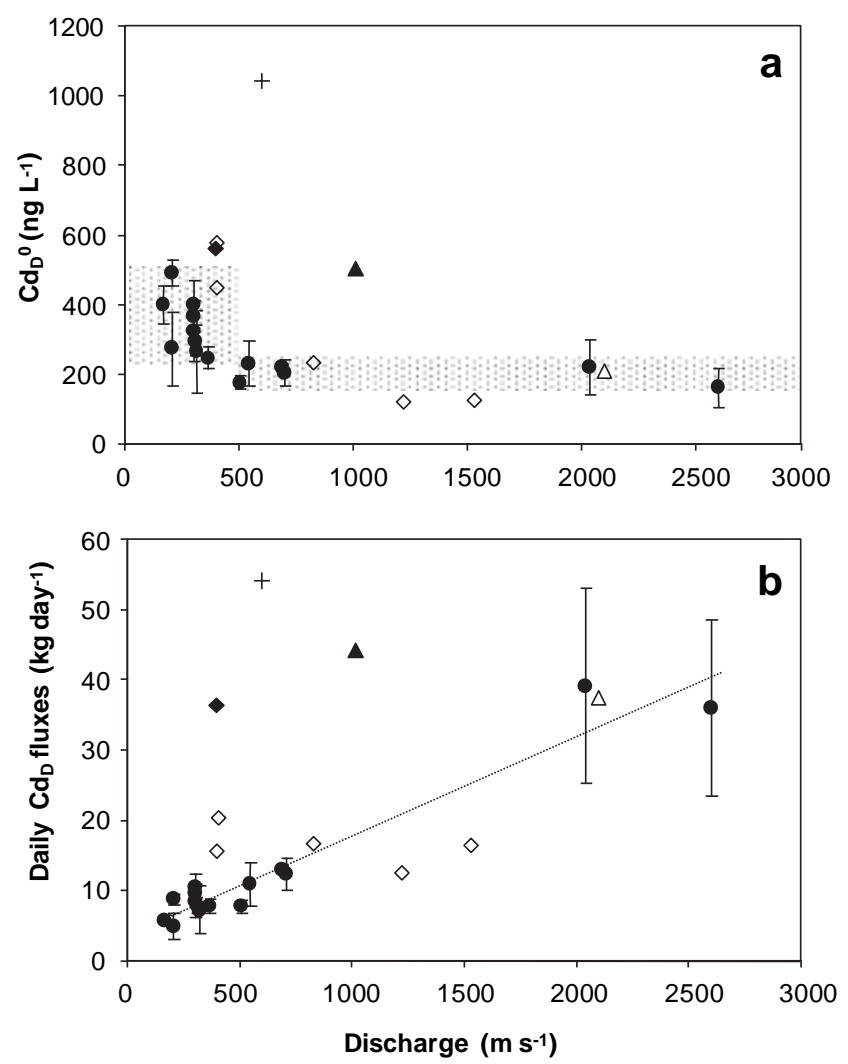

Fig. 4. Theoretic $\mathrm{Cd}^{0}{ }_{\mathrm{D}}$ Concentrations (a) and daily $\mathrm{Cd}$ fbux (b) over the whole range of discharges observed. Full circles correspond to the data of this study (2001-2007), full diamond corresponds to 1982 data (Elbaz-Poulichet et al., 1987), the cross corresponds to 1984 data (Jouanneau et al., 1990), full triangle corresponds to 1991 data (Boutier et al., 2000), open triangle corresponds to 1994 data (Kraepiel et al., 1997), and open diamonds correspond to 1997-1998 data (Michel et al., 2000). The linear correlation refers only to the data of this study (2001-2007). (too high for sulphide precipitation), despite seasonal hypoxic conditions in the fluid mud layer during pronounced low discharge conditions, (IFREMER, 1994; Abril et al., 1999). This is consistent with sulphide oxidation in the bottom of the water column induced by resuspension of anoxic sediments (Audry et al., 2007b).

Plotting $\mathrm{Cd}_{\mathrm{D}}^{0}$ concentrations over daily water discharge separates the recent (2001-2007) data into two major domains (Fig. 4a). The first relates to the low discharge period $\left(Q<500 \mathrm{~m}^{3} \mathrm{~s}^{-1}\right)$ for which $\mathrm{Cd}_{\mathrm{D}}^{0}$ values were very variable $\left(247-490 \mathrm{ng} \mathrm{L}^{-1}\right)$. Thesecond domain $\left(Q>500 \mathrm{~m}^{3} \mathrm{~s}^{-1}\right)$ regroups the flood events and intermediate freshwater discharge periods for which $\mathrm{Cd}_{\mathrm{D}}^{0}$ values were less variable (201 T $28 \mathrm{ng} \mathrm{L}^{-1}$ ).

Plotting daily $\mathrm{Cd}_{\mathrm{D}}$ net fluxes over daily water discharge shows how much $C_{D}$ net fluxes are controlled by discharge (Fig. 4b). These results are clearly different from those of Michel et al. (2000) reporting rather constant daily $\mathrm{Cd}_{\mathrm{D}}$ net fluxes in the Gironde Estuary whatever the freshwater discharge. This fundamental difference may eventually be attributed to different observation periods. The results of Michel et al. (2000) are based on one relatively dry hydrological year (1997/1998) following a succession of very wet years with numerous intense floods (1992, 1994, 1996; Scha" fer et al., 2002b). Assuming that (a) a major part of the MTZ had been expulsed out of the estuary in 1996 and the preceding wet years and (b) the MTZ may not have been well installed/renewed in $1997 / 1998$ due do low discharge, one cannot exclude that at that time the desorbable $\mathrm{Cd}$ stock in estuarine suspended particles was too low to buffer discharge-induced variations, e.g. due to dilution. Accordingly, this observation period may be considered as probably not representative of present day (2001-2007) conditions that correspond to a series of dry to average years with few isolated intense floods (Masson et al., 2007), which is not favourable to particle expulsion out of the estuary. Although the existing dataset does not allow a definitive conclusion on this point, it is evident that the hypothesis of constant daily $\mathrm{Cd}_{\mathrm{D}}$ net fluxes cannot be applied to obtain reliable flux estimates at the annual timescale.

\subsection{Daily $C d_{D}$ net fluxes}

During 2001-2007, daily $\mathrm{Cd}_{\mathrm{D}}$ net fluxes, classically estimated from the product of $\mathrm{Cd}^{0}$ and the respective daily freshwater discharge, ranged from $5 \mathrm{~kg}$ to $39 \mathrm{~kg}$ (Fig. 4b). These values are of the same order as net $C_{D}$ net fluxes reported for the Seine $(11 \mathrm{~kg}$ day $^{-1}$; Chiffoleau et al., 1999), one of the most metal contaminated estuaries in the world (Meybeck et al., 2004) and the Loire Estuaries (14 $\mathrm{kg} \mathrm{day}^{-1}$; Waeles et al., 2004). Comparing the recent daily $\mathrm{Cd}_{\mathrm{D}}$ net flux estimates for the Gironde Estuary to those obtained in 1982 (37 kg day ${ }^{-1}$ for $400 \mathrm{~m}^{3} \mathrm{~s}^{-1}$; Elbaz-Poulichet et al., 1987), 1984 (54 kg day ${ }^{-1}$ for $Q^{1 / 4} 600 \mathrm{~m}^{3} \mathrm{~s}^{-1}$; Jouanneau et al., 1990) and 1992 (44 kg day ${ }^{-1}$ for $Q^{1 / 4} 1000 \mathrm{~m}^{3} \mathrm{~s}^{-1}$; Boutier et al., 2000) shows that daily $\mathrm{Cd}_{\mathrm{D}}$ net fluxes have decreased by a factor $3-5$ during the past two decades. This probably reflects stepwise reduction of emissions in the Decazeville watershed and is in good agreement with progressive decontamination of the system discussed above. Although during the nineties alternation of dry and wet hydrological years induced some variability of particulate $\mathrm{Cd}$ inputs into the Gironde Estuary (2.5-23.0 t a ${ }^{-1}$ with a mean of 12.4 $\mathrm{t} \mathrm{a}^{-1}$; 1991-1999 period; Schä fer et al., 2002b), frequency of these variations was similar to the particle residence time in the estuary (1-2 years; Castaing and Jouanneau, 1979), which may have "smoothened" $C d_{D}$ addition resulting in more or less constant $C d_{D}$ net fluxes. In contrast, since 2000 dissolved Cd fluxes from the source to the estuary have decreased due to remediation (Audry et al., 2004b) and particulate $\mathrm{Cd}$ transport in the fluvial-estuarine system clearly changed due to increasingly frequent and long low discharge periods. For example, succession of 2-3 dry years 
followed by extreme flood events resulted in erosion and destabilisation of ancient Lot River sediment, enhanced by flood management (e.g. dam opening; Coynel et al., 2007). These processes contributed to temporarily very high $\mathrm{Cd}$ transport into the estuary followed by relatively long periods with very low $\mathrm{Cd}_{\mathrm{P}}$ fluxes (Scha" fer et al., 2002b; Coynel et al., 2007; Masson et al., 2007). Extremely long low discharge periods without renewal/ expulsion of MTZ particles (e.g. July 2004-November 2006; Fig. 2) one might expect the estuarine SPM in the MTZ to become depleted in desorbable $\mathrm{Cd}$, resulting in decreasing addition and temporarily reduced net fluxes. Replenishment and/or exchange of estuarine SPM during the following flood would then restore the estuarine stock in desorbable Cd. Accordingly, the point of time of a sampling campaign with respect to depletion/replenishment periods may eventually explain the observed variability of $\mathrm{Cd}_{\mathrm{D}}^{0}$ values during the studied low discharge situations.

\subsection{Annual $C d_{D}$ net flux estimation}

The major part (up to 95\%, unpublished data) of particulate $\mathrm{Cd}$ $\left(C_{P}\right)$ exposed to the estuarine salinity gradient is transferred to the dissolved phase before/while exported to the coastal ocean (Kraepiel et al., 1997). In fact, typical annual average $\mathrm{Cd}_{\mathrm{P}}$ concentrations (weighted by SPM fluxes) at the entry of the Gironde Estuary during the 1990-2005 period were 4-4.5 $\mathrm{mg} \mathrm{kg}^{-1}$ (after Scha” fer et al., $2002 \mathrm{~b}$; Masson et al., 2006), whereas typical particulate $\mathrm{Cd}$ concentration in MTZ particles are w0.4-0.5 mg kg-1 (Kraepiel et al., 1997; Audry et al., 2007a). Assuming that $\mathrm{Cd}_{\mathrm{D}}$ may easily enter the aquatic food chain and potentially impact the marine resources (e.g. oysters; Lekhi et al., 2008), it is important to quantify $\mathrm{Cd}_{\mathrm{D}}$ net fluxes. Ideally, annual net flux estimates should result from integration of daily net fluxes, but in reality only few daily flux estimates exist even for the most intensively observed estuaries. Thus, daily net flux estimates have to be extrapolated and the choice of the appropriate extrapolation method will determine the quality of annual net flux estimates. Some pioneer studies on net $\mathrm{Cd}_{\mathrm{D}}$ fluxes in the Gironde Estuary used one $\mathrm{Cd}(\mathrm{D}$ value multiplied by the mean annual freshwater discharge (Elbaz-Poulichet et al., 1982) or by the annual freshwater discharge of the respective year (e.g. Boutier et al., 2000). This in turn requires low seasonal variability of $\mathrm{Cd}_{\mathrm{D}}^{0}$ compared to the variability of the river water discharge.

However, both, the observation that $\mathrm{Cd}_{\mathrm{D}}{ }^{0}$ values varied with freshwater discharge during 1997/1998 (Michel et al., 2000) and the present dataset show that random $\mathrm{Cd}_{\mathrm{D}}{ }_{\mathrm{D}}$ values may be too variable to produce reliable $C d_{D}$ net flux estimates at the annual scale. In fact, multiplying the three different $\mathrm{Cd}_{\mathrm{D}}^{0}$ values reported by Michel et al. (2000) in 1997 by annual discharge would produce $\mathrm{Cd}_{\mathrm{D}}$ net flux estimates of 2.5-12.2 $\mathrm{t} \mathrm{a}^{-1}$, depending on the $\mathrm{Cd}^{0}{ }_{\mathrm{y}}$ alue used. Such high uncertainty seems to invalid the method proposed by Boutier et al. (2000). This and the high variability of $\mathrm{Cd}^{0}$ valiges obtained from our 2001-2007 dataset supports the idea that reliable annual $C d_{D}$ net flux estimates cannot be obtained from random single $\mathrm{Cd}_{\mathrm{D}}^{0}$ values especially, when they were obtained during low discharge (Fig. 4a). However, the dataset also suggests that for freshwater discharge $>500 \mathrm{~m}^{3} \mathrm{~s}^{-1}$ in the Gironde Estuary, $\mathrm{Cd}^{0}$

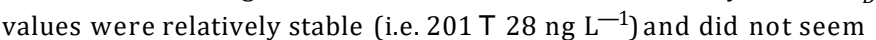
to change much during the past decade (Fig. 4a). Extrapolation of $C d_{D}$ net fluxes to the annual scale needs taking into account these discharge-dependent features. Accordingly, we suggest using different $\mathrm{Cd}^{0}{ }_{\mathrm{D}}$ for different discharge situations. For discharge $>500 \mathrm{~m}^{3} \mathrm{~s}^{-1}, \mathrm{Cd}$ falue of $201 \mathrm{~T} 28 \mathrm{ng} \mathrm{L}^{-}$shbuld provide satisfactory daily $\mathrm{Cd}_{\mathrm{D}}$ net flux estimates. For discharge $<500 \mathrm{~m}^{3} \mathrm{~s}^{-1}$, a range of $C d_{D}$ net fluxes could be estimated, by using the lowest and the highest $\mathrm{CdD}$ value observed ${ }^{\mathrm{Min}} \mathrm{Cd}^{0} \mathrm{O}_{i}<500 \mathrm{P}$ 1/4 $247 \mathrm{~T}$ $31 \mathrm{ng} \mathrm{L}^{-1}$, Max $\operatorname{Cd}_{\mathrm{D}}^{0} \partial Q_{i}<500 \mathrm{P} 1 / 4490 \mathrm{~T} 38 \mathrm{ng} \mathrm{L}^{-1} \mathrm{P}$. This would produce an estimated range of the annual $\mathrm{C} \mathrm{d}_{\mathrm{D}}$ net fluxes as follows:

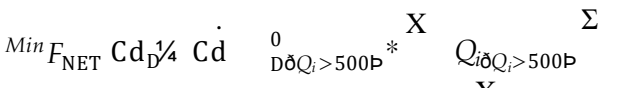

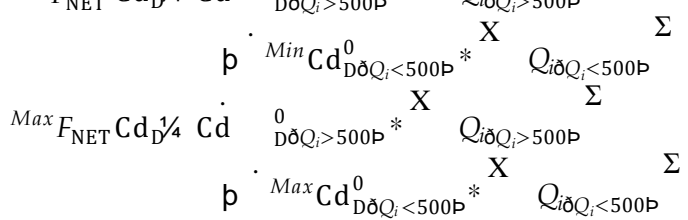

The annual $C_{D}$ net flux estimates for the 2001-2007 period obtained by this method suggest that annual $C d_{D}$ net flux ranged from 3.8-5.0 $\mathrm{t} \mathrm{a}^{-1}$ in 2005 to $6.0-7.2 \mathrm{t} \mathrm{a}^{-1}$ in 2004, depending on interannual variations in freshwater inputs (Table 2; Fig. 5). The differences between the minimum and maximum annual $\mathrm{Cd}_{\mathrm{D}}$ net flux estimates ranged through $0.8-1.3 \mathrm{t} \mathrm{a}^{-1}$, with uncertainties mainly related to the duration of low freshwater discharge situations.

\subsection{Annual net $C d$ addition}

The annual $\mathrm{Cd}_{\mathrm{D}}$ fluxes at the upstream limit of the salinity gradient ( $F_{\text {: }}$ incoming fluxes; Audry et al., 2007a,b) were estimated as follows:

$$
F_{I} 1 / 4 \operatorname{Cd}_{S^{1 / 40}}{ }^{X} \quad Q_{i}
$$

where $Q_{i}$ represents the daily freshwater discharges and $\mathrm{Cd}_{S^{1} / 40}$ represents the average $C d_{D}$ concentration measured at $S 1 / 40$ for the different campaigns $\left(\mathrm{Cd}_{S^{\prime} / 40} 1 / 417 \mathrm{~T} 5 \mathrm{ng} \mathrm{L}^{-1}\right)$. The annual net $\mathrm{Cd} D$ addition was estimated from the difference between $F_{\mathrm{NET}}$ and $F_{I}$ for each year (Table 2 ). The resulting annual $C_{D}$ addition in the salinity gradient of the Gironde Estuary ranged through 3.5-5.7 t a ${ }^{-1} \mathrm{using}$ ${ }^{M i n} F_{\text {NET }}$ and through $4.7-6.7 \mathrm{t} \mathrm{a}^{-1}$ using ${ }^{\text {Max }} F_{\text {NET }}$. This suggests that $\mathrm{Cd}_{\mathrm{D}}$ addition provides $\mathrm{Cd}$ amounts 11-16-fold higher than the incoming flux $\left(F_{I}\right)$, depending on freshwater discharge. Furthermore, $\mathrm{Cd}_{\mathrm{B}}$ addition did not seem to show a clearly decreasing trend during the observation period, despite of the generally decreasing contamination of the Lot-Garonne-Gironde fluvial-estuarine system (Fig. 5).

Dredging activities (Audry et al., 2007a,b), ongoing reload of the MTZ by Cd-rich particles from sedimentary stocks in the watershed

Annual CdD net flux, net addition and annual freshwater inputs in the Gironde Estuary during the 2001-2007 period. Annual CdD dissolved net fluxes are statistically significant

\begin{tabular}{|c|c|c|c|c|c|c|c|}
\hline & 2001 & 2002 & 2003 & 2004 & 2005 & 2006 & 2007 \\
\hline$\overline{\operatorname{Min} F_{\mathrm{NETC}} \mathrm{CdD}_{\mathrm{D}}\left(\mathrm{ta}^{-1}\right)}$ & $6.0(\mathrm{~T} 0.8)$ & $4.4(\mathrm{~T} 0.6)$ & $5.0(\mathrm{~T} 0.7)$ & $6.0(\mathrm{~T} 0.8)$ & $3.8(\mathrm{~T} 0.5)$ & $4.3(\mathrm{~T} 0.6)$ & $4.4(\mathrm{~T} 0.6)$ \\
\hline $\operatorname{Max}_{\text {NETCdD }}\left(\mathrm{ta}^{-1}\right)$ & $7.0(\mathrm{~T} 0.8)$ & $5.7(\mathrm{~T} 0.6)$ & $5.8(\mathrm{~T} 0.7)$ & $7.2(\mathrm{~T} 0.8)$ & $5.0(\mathrm{~T} 0.5)$ & $5.4(\mathrm{~T} 0.6)$ & $5.6(\mathrm{~T} 0.6)$ \\
\hline${ }^{\mathrm{Min}}$ Net addition & 5.7 & 4.0 & 4.6 & 5.5 & 3.5 & 3.9 & 4.0 \\
\hline${ }^{\mathrm{Max}}$ Net addition & 6.6 & 5.3 & 5.4 & 6.7 & 4.7 & 5.0 & 5.2 \\
\hline Annual freshwater inputs $\left(\mathrm{km}^{3}\right)$ & 28.8 & 20.8 & 24.3 & 28.0 & 17.7 & 20.6 & 21.0 \\
\hline
\end{tabular}
at the $95 \%$ confidence level. 


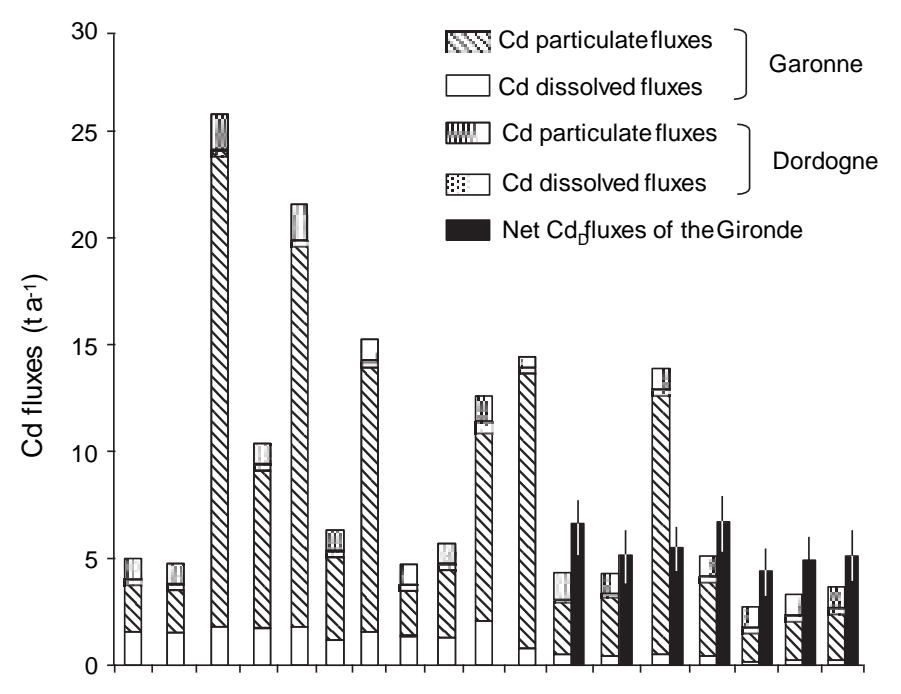

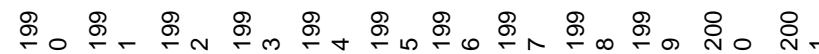

Fig. 5. Dissolved and particulate annual Cd fluxes in the Garonne and Dordogne River for the 1990-2007 period (1990-1999: Scha" fer et al., 2002a,b; 2000-2002: Masson et al., 2006; 2003-2007: unpublished data) and dissolved annual $\mathrm{Cd}_{\mathrm{D}}$ net fluxes in the Gironde Estuary for the 2001-2007 period. The errors bars represent the minimum and maximum flux estimates taking into account the $95 \%$ confidence intervals in each of these fluxes.

during flood events (Coynel et al., 2007) and/or progressive release of the estuarine Cd stock due to tidal resuspension of the bottom sediment (Robert et al., 2004) could eventually explain this relatively constant dissolved Cd net addition in the Gironde Estuary.

\subsection{Comparison between the annual $C d_{D}$ net fluxes and the gross total Cd inputs}

Estuarine mass balances need reliable estimates of gross fluxes, i.e. fluxes derived from the upstream watershed and net fluxes, i.e. fluxes leaving the estuary towards the coastal ocean. The existing observation methods allow precise and reliable estimates of gross fluxes, which are at the origin of net fluxes, but it is widely accepted that estuarine processes widely decouple gross and net fluxes (Zwolsman et al., 1997; Monbet, 2006). Accordingly, comparison of gross and net fluxes reasonably integrates larger (e.g. annual) timescales.

The annual freshwater fluxes entering the Gironde Estuary are derived from the sum of dissolved and particulate fluxes in the major tributaries, i.e. the Garonne, the Dordogne and the Isle Rivers. However, the Garonne River accounts for the majority of the highly variable and discharge-dependent SPM and Cd fluxes entering the Gironde Estuary, whereas the Dordogne River typically contributes 1.2 T $0.3 \mathrm{t} \mathrm{a}^{-1}$ (Scha" fer et al., 2002b; Fig. 5). For the 2001-2007 period, the total annual Cd gross fluvial inputs were clearly lower and less variable than during 1990-2000 (2.8-5.1 $\mathrm{t} \mathrm{a}^{-1}$; Fig. 5) except for 2003 (13.9 $\mathrm{t} \mathrm{a}^{-1}$ ), when a major flood remobilised important stocks of Cd-polluted sediment in the Lot River contributing w90\% to the high annual gross fluxes into the estuary (Coynel et al., 2007). The annual gross $\mathrm{Cd}_{\mathrm{D}}$ fluxes also tended to decrease during the observation period (2001-2007: from 0.5 to $0.2 \mathrm{t} \mathrm{a}^{-1}$ ). In contrast, annual $\mathrm{Cd}_{\mathrm{D}}$ net fluxes did not show any decreasing trend and were higher than annual gross total $\mathrm{Cd}$ fluxes in six years out of seven (Fig. 5), with a difference of w1.4 $\mathrm{T} 0.4 \mathrm{t} \mathrm{a}{ }^{-1}$. This difference has become visible only recently, due to the decreasing overall $\mathrm{Cd}$ budget of the Gironde Estuary and may reflect different sources of increasing relative importance. Atmospheric Cd wet deposition (w $7 \mathrm{ng} \mathrm{cm}^{-2} \mathrm{a}^{-1}$; Maneuxet al.,1999) would contribute w0.05 $\mathrm{t} \mathrm{a}^{-1}$ to the estuary surface and w $0.2 \mathrm{t} \mathrm{a}^{-1}$ to the adjacent watersheds. Diffuse inputs (e.g. by agriculture), urban wastewater, runoff and aerosols would also be expected to represent non-negligible $\mathrm{Cd}$ sources to the estuary.

The average particulate $\mathrm{Cd}$ concentration $\left(0.57 \mathrm{~T} 0.18 \mathrm{mg} \mathrm{kg}^{-1}\right.$, $n 1 / 491$; unpublished data) in the muddy sediments (silt and clay $>80 \%$ ) of the Gironde Estuary covering w $400 \mathrm{~km}^{2}$ (Kapsimalis et al., 2004), tend to be higher than that of SPM in the water column of the downstream estuary (0.44 $\mathrm{T} 0.04 \mathrm{mg} \mathrm{kg}^{-1}, n 1 / 4546$, unpublished data; Kraepiel et al., 1997). Assuming that tidal currents, dredging, etc. may eventually erode the uppermost $10 \mathrm{~cm}$ of these sediments and using the average concentration values in sediment and SPM, the expected Cd desorption in the salinity gradient would suggest a potential release of $\mathrm{w} 2.6 \mathrm{t}$ of $\mathrm{Cd}_{\mathrm{D}}$. However, erosion of deeper sediment layers with higher Cd concentrations (Robert et al., 2004) cannot be excluded, which would imply a higher sedimentary $\mathrm{Cd}$ stock potentially recycled. Without fundamental changes in estuarine functioning, recycling of the sedimentary $\mathrm{Cd}$ stock in the Gironde Estuary and diverse Cd inputs from diffuse

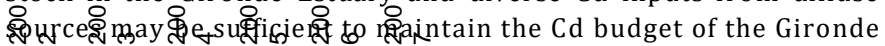
Estuary at the present level for another decade. Assuming that the present annual Cd budget of the Gironde Estuary is close to steady state, one may reasonably expect that (a) the present empirical model for $\mathrm{Cd}_{\mathrm{D}}$ net flux estimates at the annual timescale will still be valid during this period and (b) $C d_{D}$ net fluxes to the coastal ocean are forecast to decrease slowly, even when the ongoing inputs of $\mathrm{Cd}$ from the watershed continue to decrease.

\section{Conclusion}

The present work provides a very complete and recent dataset on dissolved $\mathrm{Cd}$ concentrations in the salinity gradient of the Gironde Estuary covering seven years and contrasting hydrological situations. Although $\mathrm{Cd}_{\mathrm{D}}$ concentrations along the salinity gradient followed the classical pattern, the data support substantial improvement in quantitative understanding of $\mathrm{Cd}$ behaviour in this system. Maximum $\mathrm{Cd}_{\mathrm{D}}$ concentrations in the mid-salinity range were independent from discharge and average SPM concentration. For a given cruise and salinity, $\mathrm{Cd}_{\mathrm{D}}$ concentrations in surface bottom water were similar, except during floods, suggesting limited mixing and heterogeneous water and particle residence times. Comparing recent and historic data clearly indicated a decrease by a factor 3-5 in daily $\mathrm{Cd}_{\mathrm{D}}$ net fluxes during the past two decades, mainly reflecting emission control in the Decazeville watershed. The present data revealed that during 2001-2007 daily $\mathrm{Cd}_{\mathrm{D}}$ net fluxes depended strongly on discharge, which is the contrary of the hypothesis $\left(\mathrm{Cd}_{\mathrm{D}}\right.$ net fluxes independent from discharge; Michel et al., 2000) established for the previous decade. Therefore, the commonly applied method of estimating annual $\mathrm{Cd}_{\mathrm{D}}$ net fluxes for the Gironde Estuary is not valid anymore for the present conditions. Taking into account discharge-dependent daily $\mathrm{Cd}_{\mathrm{D}}$ net fluxes, we proposed a new empirical model for $\mathrm{Cd}_{\mathrm{D}}$ net flux estimates in the Gironde Estuary at the annual timescale.

Comparing annual gross $\mathrm{Cd}$ fluxes to annual $\mathrm{Cd}_{\mathrm{D}}$ net fluxes obtained from the model revealed that neither annual $\mathrm{Cd}_{\mathrm{D}}$ addition not $C_{D}$ net fluxes showed a clear trend during 2001-2007 despite of decreasing gross fluxes. This and the fact that $C d_{D}$ net fluxes systematically exceeded total gross fluxes imply inputs by various diffuse sources. These inputs were negligible in former C d budgets, but have become significant due to decreasing fluxes from the major source in the Decazeville basin. These sources and Cd release from the sedimentary stock may keep the Cd budget of the Gironde Estuary at the present level for at least another decade, suggesting slow decontamination of the estuary, i.e. decreasing sedimentary $\mathrm{Cd}$ stocks. If $\mathrm{Cd}$ fluxes to the coastal ocean are forecast to decrease 
slowly, further work is needed to (a) quantify inputs from intraestuarine sources and (b) optimize management and control of total $\mathrm{Cd}$ inputs to accelerate the clean-up of this system and minimize future impact on the coastal zone.

\section{Acknowledgements}

We gratefully acknowledge the captains and crew members of the RV "Co^tes de la Manche" (INSU), and the following colleagues for sampling assistance, contribution to field work and analytical support: S. Audry, S. Robert, G. Lavaux and J.P. Lissalde. The support by the INSU, the CIRMAT committee and. P. Morin is acknowledged.

\section{References}

Abril, G., Etcheber, H., Le Hir, P., Bassoulet, P., Boutier, B., Frankignoulle, M., 1999. Oxic/anoxic oscillations and organic carbon mineralization in an estuarine maximum turbidity zone (The Gironde, France). Limnology and Oceanography $44,1304-1315$.

Allen, G.P., Sauzay, G., Castaing, Jouanneau, J.M., 1977. Transport and deposition of suspended sediment in the Gironde Estuary, France. In: Wiley, M. (Ed.), Estuary Process. Academic Press, New York, pp. 63-81.

Audry, S., Scha" fer, J., Blanc, G., 2004 a. Anthropogenic components on heavy metal budgets ( $\mathrm{Cd}, \mathrm{Zn}, \mathrm{Cu}$ and $\mathrm{Pb}$ ) in the Lot-Garonne fluvial system (France). Applied Geochemistry $19,469-486$

Audry, S., Scha" fer, J., Blanc, G., Jou anneau, J.M., 2004b. Fifty-year sedimentary record of heavy metal pollution $(\mathrm{Cd}, \mathrm{Zn}, \mathrm{Cu}, \mathrm{Pb})$ in the Lot River reservoirs (France) Environmental Pollution 132, 413-426.

Audry, S., Blanc, G., Scha" fer, J., Chaillou, G., Robert, S., 2006. Early diagen esis of trace metals ( $\mathrm{Cd}, \mathrm{Cu}, \mathrm{Co}, \mathrm{Ni}, \mathrm{U}, \mathrm{Mo}$ and $\mathrm{V}$ ) in the freshwater reaches of a macrotidal estuary. Geochimica et Cosmochimica Acta 70, 2264-2282.

Audry, S., Blanc, G., Scha" fer, J., Gue' rin, F., Masson, M., Robert, S., 2007 a. Budgets of $\mathrm{Mn}, \mathrm{Cd}, \mathrm{Cu}$ in the macrotidal Gironde Estuary (SW France). Marine Chemistry $107,433-448$

Audry, S., Blanc, G., Scha" fer, J., Robert, S., 2007b. Effect of estuarine sediment resuspension on early diagenesis, sulfide oxidation and dissolved molybdenum and uranium distribution. Chemical Geolology 238, 149-167.

Baeyens, W., Goeyens, L., Monteny, F., Elskens, M., 1997. Effect of organic complexation on the behaviour of dissolved $\mathrm{Cd}, \mathrm{Cu}$ and $\mathrm{Zn}$ in the Scheldt Estuary. Hydrobiologia 366, 81-90.

Blanc, G., Lapaquellerie, Y., Maillet, N., Anschutz, P., 1999. A cadmium budget for the Lot-Garonne fluvial system (France). Hydrobiologia 410, 331-341.

Boutier, B., Chiffoleau, J.F., Jouanneau, J.M., Latouche, C., Phillips, I., 1989. La contamination de la Gironde par le cadmium: origine, extension, importance. Scientific and technical report, Ifremer no. 14.

Boutier, B., Chiffoleau, J.F., Auger, D., Truquet, I., 1993. In fluence of the Loire River on dissolved lead and cadmium concentrations in coastal waters of Brittany. Estuarine Coastal and Shelf Science 36, 133-145.

Boutier, B., Chiffoleau, J.F., Gonzalez, J.L., Lazure, P., Auger, D., Truquet, I., 2000. Influence of the Gironde estuary outputs on cadmium concentrations in the coastal waters: consequences on the Marennes-Ole' ron Bay (France). Oceanologica Acta 23, 745-757

Boyle, E.A., Collier, R., Dengler, A.T., Edmond, J.M., Ng, A.C., Stallard, R.F., 1974. On the chemical mass-balance in estuaries. Geochimica Cosmochimica Acta 38 $1719-1728$.

Boyle, E.A., Huested, S.S., Grant, B., 1982. The chemical mass balance of the Amazon plume-II. Copper, nickel and cadmium. Deep Sea Research 29, 1355-1364.

Braungardt, C.B., Achterberg, E.P., Elbaz-Poulichet, F., Morley, N.H., 2003. Metal geochemistry in a mine-polluted estuarine system in Spain. Applied Geochemistry $18,1757-1771$.

Castaing, P., Jouanneau, J.M., 1979. Temps de résidence des eaux et des suspensions dans l'estuaire de la Gironde. Journal de Recherche en Oce'anographie, 41-52.

Chiffoleau, J.F., Cossa, D., Auger, D., Truquet, I., 1994. Trace metal distribution, partition and fluxes in the Seine estuary (France) in low discharge regime. Marine Chemistry 47, 145-158.

Chiffoleau, F., Auger, D., Chartier, E., 1999. Fluxes of selected trace metals from the Seine estuary to the eastern English Channel during the period August 1994 to July 1995. Continental Shelf Research 19, 2063-2082.

Claisse, D., Joanny, M., Quintin, J.Y., 1992. Le Re' seau National d'Observation de la qualite' du milieu marin (RNO). Analysis 20, 719-722.

Comans, R.N.J., van Dijk, C.P.J., 1988. Role of complexation processes in cadmium mobilization during estuarine mixing. Nature 336, 151-154.

Coynel, A., Scha"fer, J., Blanc, G., Bossy, C., 2007. Scenario of particulate trace metal and metalloid transport during a major flood event inferred from transient geochemical signals. Applied Geochemistry 22, 821-836.

Dyer, K.R., 1994. Estuarine sediment transport and deposition. Sediment Transport and Depositional Processes, 193-218.

Elbaz-Poulichet, F., Huang, W.W., Jednacak-Biscan, J., Martin, J.M., Thomas, A.J., 1982 Trace metal behaviour in the Gironde Estuary. Thalassia Jugoslavica 18, 61-95.
Elbaz-Poulichet, F., Holliger, P., Huang, W.W., Martin, J.M., 1984. Lead cycling in estuaries, illustrated by the Gironde Estuary, France. Nature 308, 409-414.

Elbaz-Poulichet, F., Martin, J.M., Huang, W.W., Zhu, J.X., 1987. Dissolved Cd behaviour in some selected French and Chinese Estuaries. Consequences on Cd supply to the ocean. Marine Chemistry 22 (2-4), 125-136.

Elbaz-Poulichet, F., Garnier, J.M., Guan, D.M., Martin, J.M., Thomas, A.J., 1996. The conservative behaviour of trace metals $(\mathrm{Cd}, \mathrm{Cu}, \mathrm{Ni}$ and $\mathrm{Pb}$ ) and as in the surface plume of stratified estuaries: example of the Rhone River (France). Estuarine, Coastal and Shelf Science 42 (3), 289-310.

Florence, T.M., 1989. Electrochemical techniques for trace elements speciation in waters. In: Batley, G.E. (Ed.), Trace Element Speciation: Analytical Methods and Problems. CRC Press, Inc., Boca Raton, Florida, pp.77-116.

Grousset, F.E., Jouanneau, J.M., Castaing, P., Lavaux, G., Latouche, C., 1999. A 70 year record of contamination from industrial activity along the Garonne River and its tributaries (SW France). Estuarine, Coastal and Shelf Science 48, 401-414.

Heral, M., Razet, D., Deslous-Paoli, J.M., Berthome' , J.P., Garnier, J., 1982. Caracte' ristiques saisonnie' res de l'hydrobiologie du complexe estuarien de Marennes Ole ron. Revue des Travaux de l'Institut des Pe^ches Maritimes 46, 97-119.

IFREMER, 1994. Estuaire de la Gironde. Livre Blanc, Final Report (Brest), Agence de l'Eau Adour Garonne.

IFREMER, 2002. Re' sultats de la surveillance de la qualite' du milieu marin littoral De partements Gironde. Landes et Pyre' né es Atlantiques, Arcachon, $60 \mathrm{pp}$.

Jouanneau, J.M., Latouche, C., 1981. The Gironde Estuary. 115 pp.

Jouanneau, J.M., Boutier, B., Latouche, C., Phillips, I., 1990. Cadmium in the Gironde fluvio-estuarine system: behaviour and flow. Science of the Total Environment 97/98, 465-469.

Jouanneau, J.M., Castaing, P., Grousset, F., Buat-Menard, P., Pedemay, P., 1999. Recording and chronology of cadmium by ${ }^{137} \mathrm{Cs}$ in the Gironde Estuary (SW France). Comptes Rendus de l'Acade' mie de Sciences, Sciences de la Terre et des Plane`tes 329, 265-270.

Kapsimalis, V., Masse' , L., Tastet, J.P., 2004. Tidal impact on modern sedimentary facies in the Gironde Estuary, Southwestern France. Journal of Coastal Research SI $41,1-11$.

Kraepiel, A.M.L., Chiffoleau, J.F., Martin, J.M., Morel, F.M.M., 1997. Geochemistry of trace metals in the Gironde estuary. Geochimica et Cosmochimica Acta 61, 1421-1436.

Lapaquellerie, Y., Jouanneau, J.M., Maillet, N., Latouche, C., 1995. Pollution en Cd dans les sé diments du Lot (France) et calcul du stock de polluant. Environmental Technology 16, 1421-1436.

Lekhi, P., Cassis, D., Pearce, C.M., Ebell, N., Maldonado, M.T., Orians, K.J., 2008. Role of dissolved and particulate cadmium in the accumulation of cadmium in cultured oysters (Crassostrea gigas). Science of the Total Environment 393 (2-3), 309325.

Li, Z.H., Nguyen, K.D., Brun-Cottan, J.C., Martin, J.M., 1994. Numerical simulation of the turbidity maximum transport in the Gironde Estuary (France). Oceanologica Acta 17, 479-500.

Maneux, E., Grousset, F.E., Buat-Me' nard, P., Lavaux, G., Rimmelin, P., Lapaquellerie Y., 1999. Temporal patterns of the wet deposition of $\mathrm{Zn}, \mathrm{Cu}, \mathrm{Ni}, \mathrm{Cd}$ and $\mathrm{Pb}$ : the Arcachon lagoon (France). Water, Air, and Soil Pollution 114, 95-120.

Martino, M., Turner, A., Nimmo, M., Millward, G.E., 2002. Resuspension, reactivity and recycling of trace metals in the Mersey Estuary, UK. Marine Chemistry 77, 171-186.

Masson, M., Blanc, G., Scha" fer, J., 2006. Geochemical signals and source contributions to heavy metal $(\mathrm{Cd}, \mathrm{Zn}, \mathrm{Pb}, \mathrm{Cu})$ fluxes into the Gironde Estuary via its major tributaries. Science of the Total Environment 370, 133-146.

Masson, M., Scha" fer, J., Blanc, G., Pierre, A., 2007. Seasonal variations and annual fluxes of arsenic in the Garonne, Dordogne and Isle Rivers, France. Science of the Total Environment 373, 196-207.

Meybeck, M., Horowitz, A.J., Grosbois, C., 2004. The geochemistry of seine river basin particulate matter: distribution of an integrated metal pollution index. Science of the Total Environment 328, 219-236.

Michel, P., Boutier, B., Chiffoleau, J.F., 2000. Net fluxes of dissolved arsenic, cadmium, copper, zinc, nitrogen and phosphorous from the Gironde Estuary (France): seasonal variations and trends. Estuarine, Coastal and Shelf Science 51, $451-462$.

Monbet, P., 2006. Mass balance of lead through a small macrotidal estuary: the Morlaix River Estuary (Brittany, France). Marine Chemistry 98, 59-80.

Owens, R.E., Balls, P.W., 1997. Dissolved trace metals in the Tay Estuary. Estuarine, Coastal and Shelf Science 44, 421-434.

RNO, 2006. Bulletin de Surveillance du milieu marin, travaux du Re'seau National d'Observation de la Qualite' du Milieu Marin. Ifremer.

Robert, S., Blanc, G., Scha"fer, J., Lavaux, G., Abril, G., 2004. Metal mobilization in the Gironde Estuary (France): the role of the soft mud layer in the maximum turbidity zone. Marine Chemistry 87, 1-13.

Scha" fer, J., Blanc, G., Bossy, C., Gue' rin, F., Lapaquellerie, Y., Lavaux, G., Lissalde, J.P., Masson, M., Maillet, N., Robert, S., 2002a. Budget of the metal inputs into the Gironde Estuary: Cd desorption process in the salinity gradient (Bilan des apports mé talliques à l'estuaire de la Gironde: processus de de' sorption de cadmium dans le gradient de salinite' ). Final scientific report, Liteau Program.

Scha” fer, J., Blanc, G., Lapaquellerie, Y., Maillet, N., Maneux, E., Etcheber, H., 2002 b. Ten-year-observation of the Gironde tributary fluvial system: fluxes of suspended matter, particulate organic carbon and cadmium. Marine Chemistry 79 229-242. 
Scha" fer, J., Blanc, G., Audry, S., Cossa, D., Bossy, C., 2006. Mercury in the Lot-Garonne River system (France): sources, fluxes and anthropogenic component. Applied Geochemistry 21, 515-527.

Shiller, A.M., Boyle, E.A., 1991. Trace elements in the Mississippi River Delta outflow region: behaviour at high discharge. Geochemica Cosmochemica Acta 55, $3241-3251$

Sottolichio, A., Castaing, P., 1999. A synthesis on seasonal dynamics of highlyconcentrated structures in the Gironde Estuary. Comptes Rendus de l'Academie de Sciences, Sciences de la Terre et des Planetes 329, 795-800.

Tang, D., Warnken, K.W., Santschi, P.H., 2002. Distribution and partitioning of trace metals (Cd, $\mathrm{Cu}, \mathrm{Ni}, \mathrm{Pb}, \mathrm{Zn}$ ) in Gavelston Bay waters. Marine Chemistry 78, 29-45.

Turner, A., Millward, G.E., Bale, A.J., Morris, A.W., 1993. Application of the KD concept to the study of trace metal removal and desorption during estuarine mixing. Estuarine, Coastal and Shelf Science 36, 1-13.

Turner, A., 1996. Trace-metal partitioning in estuaries: importance of salinity and particle concentration. Marine Chemistry 54, 27-39.
Waeles, M., Riso, R.D., Maquer, J.F., Le Corre, P., 2004. Distribution and chemical speciation of dissolved cadmium and copper in the Loire estuary and North Biscay continental shelf, France. Estuarine, Coastal and Shelf Science 59, 49-57. Waeles, M., Riso, R.D., Le Corre, P., 2005. Seasonal variations of cadmium speciation in the Penze' Estuary, NW France. Estuarine, Coastal and Shelf Science 65, $143-152$

Wen, L.S., Santschi, P., Gill, G., Paternostro, C., 1999. Estuarine trace metal distribution in Gavelston Bay: importance of colloidal forms in the speciation of the dissolved phase. Marine Chemistry 63, 185-212.

Windom, H., Smith Jr., R., Rawlinson, C., Hungspreugs, M., Dharmvanij, S., Wattayakorn, G., 1988. Trace metal transport in a tropical estuary. Marine Chemistry 24, 293-305.

Zwolsman, J.J.G., Van Eck, B.T.M., Van Der Weijden, C.H., 1997. Geochemistry of dissolved trace metals (cadmium, copper, zinc) in the Scheldt estuary, southwestern Netherlands: impact of seasonal variability. Geochimica et Cosmochimica Acta 61, 1635-1652. 